\section{Nitzschia Cultures at Hull and at Plymouth}

More than thirty years ago a persistent culture of a minute diatom was obtained by Allen and Nelson ${ }^{1}$; they refer to it as Nitzschia closterium, W. Sm., forma minutissima. This persistent culture has been maintained at Plymouth ever since, and has been distributed to many workers at home and abroad. The species has proved to be a useful food for many kinds of marine larvæ and a convenient diatom for experimental work. A sample was sent to Hull about 1930 and has been grown there until the present time. When first sent the great majority of the frustules, as at Plymouth, were of the straight or slightly curved fusiform shape characteristic of the species, but in 1932 a very few three-rayed or triradiate cells were present; their abundance was certainly much less than $l$ per cent. In cultures derived from Plymouth stock such cells have been seen by other workers, notably by Barker ${ }^{2}$. By 1934 there had, at Hull, been a slight increase in the abundance of these tri-radiates and they may have formed as much as 1 per cent of the cultures. In 1936 the proportion had risen to more than 50 per cent. Thereafter the abundance of tri-radiates steadily increased so that by the spring of 1939 they comprised 97 per cent, and by the summer of 1941 more than 99 per cent, of the cultures.

The Plymouth stock cultures first passed into the care of one of us late in 1937, from which time two strains have been kept. In 1939, when attention was specially directed to them, well over 90 per cent of the frustules were tri-radiate, indeed in one strain the culture was almost entirely tri-radiate. By June 1941 both strains were about 99 per cent tri-radiate. In 1939 two clone cultures of normal cells and one clone culture of tri-radiates were established, a sample of the latter-as well as of one of the formerbeing sent to Hull in February 1940 and maintained there by sub-culturing. All clone cultures for long remained almost true to type : after the first few months a very few cells of the alternate kind were to be seen : lately, there have been some significant changes. At Plymouth one clone normal (the clone normal not sent to Hull) has become about 5 per cent tri-radiate, but the other clone normal at Plymouth and at Hull is still almost pure. It is, however, to the tri-radiate cultures that attention is here directed.

The two strains of Plymouth stock and the clone, all three about 99 per cent tri-radiate in the preceding June, had by November 1941 produced large numbers of normal cells. There is little doubt from the appearance of the cultures that this was done by the gradual reduction and eventual elimination of one ray of the tri-radiate, for of the remaining tri-radiates a large proportion had one ray reduced. Another process by which normals may derive from tri-radiates is known' but does not appear to have played any part in this particular change-over. The very remarkable feature is that while these changes were taking place at Plymouth almost identical changes were occurring in the cultures at Hull : until a short time ago neither author was aware of this fact. Even the pircentages are now closely similar, as the following table shows. It is based on sub-cultures made at the end of November 1941 and counted recently when dense.

The almost parallel recent history of these cultures, grown so far apart and differently treated as to time
Plymouth Stock 569

$$
\begin{gathered}
\text { " } \quad \text { clone tri-radiate } \\
\text { Hull Standard Stock } \\
\text {, General , } \\
\text {, clone tri-radiate }
\end{gathered}
$$

\begin{tabular}{|c|c|}
\hline June 1941 & February 1942 \\
\hline $99 \cdot 3$ & $61 \cdot 6$ \\
\hline $98 \cdot 6$ & $64 \cdot 7$ \\
\hline $98 \cdot 8$ & $60 \cdot 3$ \\
\hline & $62 \cdot 0$ \\
\hline$>99 \cdot 0$ & $64 \cdot 5$ \\
\hline & $68 \cdot 25$ \\
\hline
\end{tabular}

Percentage tri-radiate

and frequency of sub-culturing, lighting, temperature, etc., is so striking that we are anxious to hear from anyone who, in the past ten years, has kept cultures of this diatom, especially if their cultures be derived originally from Plymouth stock. It is hoped to include in a paper to be published later any relevant okservations other workers may be able to contribute.

D. P. WIIson.

$$
\begin{gathered}
\text { Marine Biological Laboratory, } \\
\text { Citadel Hill, } \\
\text { Plymouth. }
\end{gathered}
$$

\section{E. LUCAS.}

Dept. of Zoology and Oceanography,

University College.

Hull.

March 2.

${ }^{1}$ Allen, E. J., and Nelson, E. W., J. Mar. Biol. Assoc., 8, 421 (1910). 'Barker, H. A., Archiv Mikrobiol., 6, 141 (1935).

\section{Occurrence of a Halophilic Alga in Mid-Cheshire}

ON October 26, while conducting some preliminary investigations in the course of an ecological survey of a salt-spring situated at Aldersey ${ }^{1}$, seven miles south-south-east of Chester, the filamentous alga Percursaria percursa (formerly known as Enteromorpha percursa (Ag.)) was encountered. The presence of this alga is interesting because Percursaria is usually found in rock pools on the shore between tide marks. The only previous record of Percursaria from a brackish non-coastal region, which has come to my notice, is that mentioned by Grove ${ }^{2}$ from brackish waters in the Midlands. The alga was evidently found in a ditch near the canal at Salwarp, Worcestershire. A note of this find is recorded by West and Fritsch ${ }^{3}$. The species is described and figured by Newton 4 .

Percursaria percursa occurs in large masses at the Aldersey spring and is spreading into a neighbouring brackish gutter. The spring water, at the time the specimen was collected, had a salinity of 1,675 parts per 100,000 and a $p \mathrm{H}$ value of $7 \cdot 0$ (Lovibond comparator).

I gratefully acknowledge the assistance of Dr. Helen Blackler, of the Liverpool Museum, and Mr. E. G. Williams, of Chester, for their independent identifications of the alga.

12 Queen's Road,

Frederick Burke. Chester.

March 3.

1 Sheriock, Mem. Geol. Survey, Mineral Resources of Gt. Brit. Rocksalt and Brine, 18, 111 (1921).

s. Bot., 68, 33 (1920).

s "British Freshwater Algæ", p. 162 (1927).

- Brit. Museum: Handbook of British Seaweeds (1931). 